\title{
Public finances in the EU-27: Are they sustainable?
}

\author{
Juan Carlos Cuestas ${ }^{1}$, Luis A. Gil-Alana ${ }^{2}$ and Laura Sauci ${ }^{3}$ \\ ${ }^{1}$ Jaume I University, Castellon, Spain \\ ${ }^{1}$ Eesti Pank and Tallinn University of Technology, Tallinn Estonia \\ ${ }^{2}$ University of Navarra, Pamplona, Spain \\ ${ }^{3}$ University of Huelva, Huelva, Spain
}

\begin{abstract}
In this paper we aim to analyse the degree of mean reversion of public expenditure, revenue and the difference between them, over GDP for 27 European Union (EU) countries. To gain flexibility in the analysis of the order of integration of the variables we apply fractional integration techniques. In general, we find evidence of mean reversion in all countries.
\end{abstract}

Key words: Public revenues; Public expenditures; Fractional integration.

JEL classification: C32; E62; H60.

* Corresponding author: Prof. Luis A. Gil-Alana

University of Navarra

Faculty of Economics and ICS (NCID)

Edificio Amigos

E-31080 Pamplona

SPAIN

Email: Alana@unav.es

\footnotetext{
Juan Carlos Cuestas and Luis Gil-Alana gratefully acknowledge the financial support from the research grant ECO2017-83255-C33-P and ECO2017-85503-R 'Programa Estatal de Fomento de la Investigación, Científica y Técnica de Excelencia, Subprograma Estatal de Generación de Conocimiento, Ministerio de Economía, Industria y Competitividad (MINEIC), Gobierno de España, 2018-2020'. Comments from an anonymous referee and the editor are gratefully acknowledged. The usual disclaimer applies.
} 


\section{Introduction}

Since the collapse of Lehman Brothers in 2008, and the breakout of the global financial crisis, many affected countries aimed to reduce their public debt stocks by applying contractionary fiscal policies. The reason behind this was the escalation in the levels of debt amid previously applied countercyclical expansionary policies. There is considerable literature on the degree of fiscal budget sustainability, see next section, which applies tests for the order of integration of fiscal budget over GDP. However, it is important for policy decisions to understand how its components, namely public expenditure and revenue over GDP, in addition to the difference between these, react after a shock.

In this paper we apply fractional integration techniques in order to gain flexibility in the analysis of the order of integration of these macrovariables in a group of $27 \mathrm{EU}$ countries. As far as we know, this is one of the few papers that analyse this issue from a fractionally integrated perspective and the first in the context of the EU countries. If the order of integration is greater than 1, then shocks have permanent effects, whereas if it is less than 1, the effects are only transitory. In the former, policy intervention is necessary to counteract exogenous shocks, whereas in the latter it would only depend on the speed of mean reversion, which is faster the closer the order of integration is to 1. Given that some EU countries have needed bailouts after the collapse of their public balances, the analysis of the mean reversion of fiscal budget and its components has gathered momentum. This is of particular importance since, in a monetary union, there is no possibility to finance public deficits through monetary expansion by the national central banks. Hence the probability of default increases (De Grauwe, 2012). 
In a seminal contribution, Bohn (2007) explains that the transversality condition of the intertemporal budget constraint can be satisfied for any arbitrary order of integration of the fiscal deficit, for a sufficiently large discount factor. Hence, one cannot really assess sustainability testing for stationarity of the fiscal deficit. In this paper, we are interested in analysing how the three magnitudes, i.e. expenditure, revenue and the difference between them, over GDP, react after a shock and we call for caution in the non-mean reverting cases.

The contributions of the paper are the following: First we examine the public finances from a time series viewpoint using a novel methodology based on the concepts of long memory and fractional integration. In doing so, we permit a more degree of flexibility than the standard methods that are based on stationarity, $I(0)$, or nonstationarity, I(1), models. Second, there are not empirical papers that use this methodology in the context of the 27 EU countries. Finally, the implications of the shocks using this method are also examined in the paper.

There are many different ways to assess sustainability. The S0, S1 and S2 indicators are another way to assess it. Our measures are complementary to those, in the sense that rather than looking at the values of debt, we look at how countries accumulate debt. That is, we look into how past flows into the stock of debt affect the speed at which does flows generate. In order words, we analyse if the countries generate debt in an explosive manner. Hence, the values of debt or public deficits may not be very high, but a country might be generating then at a high speed every year, which could be seen as an indication that something is wrong.

The layout of the paper is as follows: Section 2 deals with a brief revision of the literature on this specific issue. Section 3 presents the methodology used in the paper 
which is based on fractional integration, making especial emphasis in the fact that this methodology allows for studying in a more flexible way the nature of the shocks which may be transitory or permanent. Section 4 describes the dataset and the results. Finally, Section 5 concludes the paper.

\section{Literature review}

Sustainability of fiscal policy has been an issue widely addressed in the literature over decades, coming back again to the heart of the debate after the 2008 global financial crisis. Initially, the majority of the empirical works ${ }^{1}$ examine this hypothesis for U.S. time series data, either from a univariate approach, testing the non-stationary of budget deficits or public debt by applying different unit root tests (Hamilton and Flavin, 1986; Wilcox, 1989), or from a multivariate approach, assessing the long-run relationship between public revenues and expenditures (Trehan and Walsh, 1988; Hakkion and Rush, 1991; Haug, 1991, 1995; Ahmed and Rogers, 1995; Quintos, 1995; Crowder, 1997; Martin, 2000). Other studies attempt to unify both approaches (Trehan and Walsh, 1991; Berenguer-Rico and Carrión-i-Silvestre, 2011) or suggest alternative methods to test the fiscal sustainability (Bohn, 1998, 2007; Yoon, 2012). We also find works that re-examine this issue, highlighting the importance of allowing for structural breaks in the analysis (Quintos, 1995; Martin, 2000; Cunado et al., 2004; BerenguerRico and Carrión-i-Silvestre, 2011) or reaching a certain threshold for a mean-reverting behaviour of budget deficit (Arestis et al., 2004; Payne and Mohammadi, 2006; Cipollini et al., 2009). Examples of empirical literature for other economies are also numerous. We can point out single-country studies, for instance, for the case of

\footnotetext{
${ }^{1}$ For a comprehensive literature review, see e.g. Afonso (2005) and Paparas et al. (2015).
} 
Australia (Elliot and Kearney, 1988; Olekalns, 2000); the United Kingdom (Lusinyan and Thornton, 2011; Fan and Arghyrou, 2012); Spain (Bajo-Rubio et al., 2004, 2006, 2014); Portugal (Marinheiro, 2006; Correia et al., 2008); Austria (Getzner et al., 2001); Germany (Greiner et al., 1999, 2006) or Sweden (Hatemi-J, 2002), among others, as well as, for a set of countries such as the G-7 (Payne, 1997; Feve and Henin, 2000; Chen, 2014) or some EU/EMU members (Bravo and Silvestre, 2002; Greiner et al., 2004; Afonso, 2005; Argyrou and Luintel, 2007; Cuestas and Staehr, 2013; Afonso and Tovar, 2017). Both the methodology and the main results of such studies are summarized in Table 1.

Focusing on our sample, we can mention some previous works based on EU quarterly data which take into account multiple structural changes and the presence of nonlinearities in the analysis. For instance, Argyrou and Luintel (2007) examine both the strong- and weak-sense of fiscal sustainability for a sample of four EMU economies -Greece, Ireland, Italy and the Netherlands- In their research, the authors find evidence that the fiscal policy in all of them is sustainable, detecting the presence of multiple regime shifts, one of which can be attributed to the Maastricht Treaty. In addition, their results point to the existence of a non-linear behavior in the adjustment of fiscal disequilibrium. Other authors such as Cuestas \& Staehr (2013) study the persistence of the fiscal balance in percent of GDP of ten Central and Eastern European countries. They find out that in the long term, the series exhibit a mean-reverting behavior after controlling for structural changes, but this scenario is vulnerable and depend, in the medium term, on the effect of global financial crisis. More recently, Chen (2014), using different threshold autoregressive (TAR) models, analyses fiscal sustainability of the debt-GDP ratio for the G-7 and some European countries -Greece, 
Ireland, Portugal and Spain-. Evidence seems to be mixed, depending on the type of linear or non-linear unit root tests applied. The results from TAR model show for the majority of countries that the government's intertemporal budget constraint holds in the long run. The results from variants of TAR model reveal that the debt-GDP ratios of Canada, Germany, the US and Italy are stationary when a non-linear trend is considered. Finally, Alfonso and Tovar (2017) revisit the relationship between the primary budget surplus and the debt-to-GDP ratio using a sample of eleven Euro-area countries over the period 1999Q1 and 2013Q4. Their results show evidence of sustainability in Belgium, France, Germany, and the Netherlands, highlighting the negative impact of the global financial crises on fiscal sustainability. Table 1 summarizes the literature review in a comprehensive way.

\section{[Include Table 1 about here]}

Overall we can say that the evidence is mixed and far from conclusive. The contribution of this paper lies in the analysis of the reaction to shocks not only for the fiscal deficit, but also for its main components, revenue and expenditure as a percentage of GDP. To gain flexibility in the analysis instead of relying on unit root or stationarity tests, we use fractional integration methods which break the dichotomy of integer orders of integration. In this way we may be able to see whether a potential escalating deficit is due to the expenditure side or the revenue side.

\section{Methodology}

We use techniques which are based on the concept of fractional integration. This basically means that the number of differences required in a time series to render it $\mathrm{I}(0)$ stationarity may be a fractional value, allowing thus for a higher flexibility in the 
dynamic specification of the data than those models based on classical methods and that only use integer degrees of differentiation, usually 0 or 1 . Thus, $\mathrm{x}_{\mathrm{t}}$ is said to be integrated of order $\mathrm{d}$, and denoted as $\mathrm{x}_{\mathrm{t}} \approx \mathrm{I}(\mathrm{d})$ if it can be represented as:

$$
(1-L)^{d} x_{t}=u_{t}, \quad t=1,2, \ldots
$$

where $\mathrm{L}$ is the lag operator (i.e., $\mathrm{Lx} \mathrm{x}_{\mathrm{t}}=\mathrm{x}_{\mathrm{t}-1}$ ), and $\mathrm{u}_{\mathrm{t}}$ is $\mathrm{I}(0)$ (or "short memory"), defined as a covariance stationary process where the infinite sum of the autocovariances is finite. In this context, if $\mathrm{d}>0, \mathrm{x}_{\mathrm{t}}$ belongs to a wider class of models called "long memory", so-named because of the strong degree of association between observations which are far away in time. These processes, originally proposed in the 80s by Granger (1980, 1981), Granger and Joyeux (1980) and Hosking (1981) garnered popularity fifteen years later when its use was generalized in the analysis of macroeconomic and financial data (see, e.g. Baillie,1996; Gil-Alana and Robinson, 1997; Michelacci and Zaffaroni, 2000). The main advantage of this method is that it is more general than the standard methods, in the sense that it includes the standard cases of stationarity, I $(0)$, and nonstationarity, $\mathrm{I}(1)$, as particular cases of interest when $\mathrm{d}$ is equal to 0 and 1 respectively. Another advantage of this approach is that the fractional differencing parameter will provide us with information about the degree of persistence of the data. Moreover, this is a very flexible approach that permits us to consider nonstationary persistence though mean reverting processes if the differencing parameter is in the range $[0.5,1)$. In this context, the longer the value of $d$ is, the longer the time the series to be recovered will be, while if $\mathrm{d}$ is equal to or higher than 1 shocks will have a permanent nature and strong measures will have to be adopted to recover the original trends. 


\section{Data and Empirical Results}

In this section we describe the dataset and present the results for the fiscal sustainability analysis. The database has been obtained from EUROSTAT and corresponds to quarterly non-financial accounts for general government. The variables studied are total expenditure and total revenue as percentages of gross domestic product. We use unadjusted data (i.e. neither seasonally adjusted nor calendar adjusted data) due to their greater availability for longer time series. Our sample covers $27 \mathrm{EU}$ countries over the period 1999Q1- 2014Q1, for the majority of them. ${ }^{2}$ We only consider countries that have at least 50 observations for each variable, being excluded for this reason, Croatia, with 9 observations (from 2012Q1 to 2014Q1).

Across this section and to allow for some deterministic terms, we consider the following model,

$$
y_{t}=\alpha+\beta t+x_{t}, \quad(1-L)^{d} x_{t}=u_{t}, \quad t=1,2, \ldots,
$$

where the errors are assumed to follow in turn a white noise process. Across the tables we display the estimates of $d$, along with their corresponding $95 \%$ confidence bands, for the three cases of i) no deterministic terms, ii) a constant, and iii) a constant and a linear time trend. Table 2 focuses on the expenditure/GDP ratio (in logs); Table 3 on revenue/GDP, while Table 4 on the differences between the two series.

Starting with the expenditure/GDP ratio and looking first at the deterministic terms, we observe that the time trend is required in half of the countries (14), while for

2 Countries with data from 1999Q1 to 2014Q1 are: Austria, Bulgaria, Czech Republic, Denmark, Estonia, Greece, Hungary, Ireland, Italy, Latvia, Lithuania, Luxembourg, Poland, Portugal, Slovakia, Slovenia, The Netherlands. For the remaining countries, the initial period for the analysis is: the United Kingdom (1987Q1); Belgium and France (1991Q1); Sweden (1993Q1); Germany, Spain and Cyprus (1995Q1); Romania and Finland (1998Q1) and Malta (2000Q1). 
the thirteen remaining, the intercept seems to be sufficient to describe this component. From the fourteen countries where the time trend is required, the time trend coefficient is significantly positive in 10 of them, while in four countries, the time trend is found to be negative (Bulgaria, Germany, Slovak Republic and Sweden). ${ }^{3}$ Focusing on the estimated values of $\mathrm{d}$, we can look at the second column of Table 5 that reports a summary of Tables $2-4$ focusing exclusively on the selected models according to the deterministic terms. We see in this table that long memory (i.e., statistical evidence of $d$ $>0$ ) is found in 16 of the countries examined. France, Finland and the UK also display large degrees of persistence (with estimates of $d$ respectively of $0.71,0.69$ and 0.64 ) but the unit root null is in these cases rejected in favor of mean reversion $(d<1)$. At the other extreme, we have 6 countries with significantly negative values of d: Italy $(-0.50)$, Cyprus (-0.29), Portugal (-0.24) and Bulgaria, Hungary and Malta (-0.16). For the remaining countries the $\mathrm{I}(0)$ hypothesis cannot be statistically rejected.

\section{[Insert Tables 2 -5 about here]}

Next we move to the revenue/GDP ratio. The results for the three cases of no terms, an intercept and an intercept with a linear time trend are displayed in Table 2. We observe in this table that the intercept is required in 12 countries, while the time trend seems to be required in the remaining 15 , with 10 positive trends and 5 countries showing a negative slope. The estimates of $d$ in this table are substantially smaller than in the case of the expenditure/GDP ratio, and we only observe 4 countries displaying long memory ( $\mathrm{d}>0$ ) behavior: Sweden (0.71), Slovak Republic (0.32), and Greece and Lithuania (0.23); on the other hand there are eight countries with anti-persistence $(d<0)$

3 Note that in the context of fractional integration with $\mathrm{d}>0$, the time trend coefficient becomes irrelevant since it tends to a constant in the long run. 
behavior, being especially noticeable the cases of Portugal (-0.51), and Romania (-0.50). The remaining countries show $\mathrm{I}(0)$ behavior.

Table 3 focuses on the differences between expenditures and revenues (in logs). Starting once more with the deterministic terms, we observe three countries with no deterministic terms (Bulgaria, Denmark and Estonia); there is a group of 11 countries which require an intercept; and the time trend is statistically significant in the remaining 13 (with 9 positive trends and 4 negative ones). Focusing now on the differencing parameter, long memory is found in 15 countries. Large degrees of integration are also obtained in the cases of Denmark (0.60) and the UK (0.42) and anti-persistence is only found in two countries: Italy (-0.29) and Austria (-0.25).

In general it is found that there is no evidence of lack of mean reversion for the countries analysed, with a few exceptions. For the cases of Sweden and Denmark, although we do not find evidence of explosive or unit root behavior, it is important to highlight the slow speed of mean reversion of their fiscal balance, which also may ring some alarm bells.

\section{Summary and Conclusions}

There has been increasing concern on the sustainability of public deficits in Europe amid the global financial crisis and the Great Recession. The background of this analysis is related to the fact that some European economies have needed bailouts.

With the aim of providing more evidence for policy purposes on the issue of fiscal sustainability in Europe, we have analyzed the order of integration of public expenditure, revenue and the difference between them, over GDP, in Europe. 
To keep the analysis simple and focused, we have applied fractional integration techniques is order to analyze the mean-reverting behavior of those three variables. This methodology is more general than the classical one based on integer degrees of differentiation and seems to be more appropriate to analyze the nature of the shocks from a very flexible viewpoint. We then find that these three variables behave in most cases as mean reverting processes, some of them also displaying long memory behavior. The main implication is that shocks will tend to disappear by themselves with no need of strong policy actions to recover the original trends.

The possibility of structural breaks is an issue that has not been taken into account in this paper. This is relevant, especially noting that some authors have argued that fractional integration might be an artificial artifact generated by the presence of breaks not taken into account (see, e.g, Diebold and Inoue, 2001; Granger and Hyung, 2004; etc.). However, given the sample size in our case, the inclusion of breaks would produce subsamples with very few observations invalidating the analysis based on fractional integration. On the other hand, issues such as causality, endogeneity or the omission of relevant variables have not been taken into account in the univariate models presented in this work since our approach was based on examining the statistical properties from the data following the approach of "let the data speak by themselves". All these questions will be investigated in future papers. 


\section{References}

Afonso, A. (2005). Fiscal sustainability: The unpleasant European case, FinanzArchiv, 61(1), 19-44.

Afonso, A., \& Tovar, J. (2017). Euro area time-varying fiscal sustainability, International Journal of Finance \& Economics, 22, 244-254.

Ahmed, S., and Rogers, J. (1995), Government Budget Deficits and Trade Deficits. Are Present Value Constraints Satisfied in Long-term Data?, Journal of Monetary Economics, 36, 351-374.

Arestis, P., Cipollini, A., \& Fattouh, B. (2004). Threshold effects in the U.S. budget deficit, Economic Inquiry, 42(2), 214-222.

Arghyrou, M.G., \& Luintel, K.B. (2007). Government solvency: revisiting some EMU countries, Journal of Macroeconomics, 29(2), 387-410.

Baillie, R.T. (1996). Long memory processes and fractional integration in econometrics, Journal of Econometrics, 73(1), 5-59.

Bajo-Rubio, O., Diaz-Roldan, C., \& Esteve, V. (2004). Searching for threshold effects in the evolution of budget deficits: An application to the Spanish case, Economic Letters, 82(2), 239- 243.

Bajo-Rubio, O., Diaz-Roldan, C., \& Esteve, V. (2006). Is the budget deficit sustainable when fiscal policy is non-linear? The case of Spain, Journal of Macroeconomics, 28, 596-608.

Bajo-Rubio, O., Diaz-Roldan, C., \& Esteve, V. (2014). Deficit sustainability, and monetary versus fiscal dominance: The case of Spain, 1850-2000, Journal of Policy Modeling, 36, 924-937.

Berenguer-Rico, V., \& Carrion-i-Silvestre, J.L. (2011). Regime shifts in stock-flow I(2)-I(1) systems: The case of US fiscal sustainability, Journal of Applied Econometrics 26, 298-321

Bohn, H. (2007) Are stationarity and cointegration restrictions really necessary for the intertemporal budget constraint?, Journal of Monetary Economics, 54, 1837-1847.

Bohn, H. (1998). The behavior of U. S. public debt and deficits, Quarterly Journal of Economics, 113(3), 949-963.

Bravo, A., \& Silvestre, A. (2002). Intertemporal sustainability of fiscal policies: some tests for European countries, European Journal of Political Economy, 18(3), 517-528. 
Chen, S-W. (2014). Testing for fiscal sustainability: New evidence from the G-7 and some European countries, Economic Modelling, 37, 1-15.

Cipollini, A., Fattouh, B., \& Mouratidis, K. (2009). Fiscal readjustments in the United States: A nonlinear time-series analysis, Economic Inquiry, 47(1), 34-54.

Corsetti G. and Roubini N. (1991). Fiscal deficits, public debt and government solvency: Evidence from OECD countries, Journal of Japanese and International Economies, 5, 354-80.

Correia, D. R. M., Neck, R., Panagiotidis, T., \& Richter, R. (2008). An empirical investigation of the sustainability of the public deficit in Portugal, International Economics and Economic Policy, 5(1), 209-223.

Crowder, W. J. (1997). The U.S. federal intertemporal budget constraint: Restoring equilibrium through increased revenues or decreased spending?, Working Paper, University of Texas at Arlington.

Cunado, J., Gil-Alana, L.A., \& Gracia, F.P. (2004). Is the US fiscal deficit sustainable? A fractionally integrated approach, Journal of Economics and Business, 56(6), 501-526.

Cuestas, J.C., \& Staehr, K.(2013). Fiscal shocks and budget balance persistence in the EU countries from Central and Eastern Europe, Applied Economics, 45:22, 32113219.

De Grauwe, P. (2012). Governance of a fragile Eurozone. Australian Economic Review $45,25-268$.

Diebold, F.X. and Inoue, A. (2001). Long memory and regime switching. Journal of Econometrics, 105, 131-159.

Elliot, G., \& Kearney, C. (1988). The intertemporal government budget constraint and tests for bubbles, Research Discussion Paper, 8809, Reserve Bank of Australia.

Fan, J., \& Arghyrou, M. (2012). UK fiscal policy sustainability, 1955-2006, The Manchester School, 19(3).

Feve, P., \& Henin, P. (2000). Assessing effective sustainability of fiscal policy within the G-7, Oxford Bulletin of Economics \& Statistics, 62(2), 175-195.

Fountas, S., \& Wu, J.L. (1996). Are the Greek budget deficits too large?, Applied Economics Letters, 3(7), 487-490.

Getzner, M., Glatzer, E., and Neck, R. (2001). On the sustainability of Austrian budgetary Policies, Empirica, 28, 21-40. 
Gil-Alana, L.A. and Robinson, P.M. (1997). Testing of unit roots and other nonstationary hypothesis in macroeconomic time series, Journal of Econometrics, 80(2), 241-268.

Granger, C.W.J. (1980). Long memory relationships and the aggregation of dynamic models, Journal of Econometrics, 14, 227-238.

Granger, C.W.J. (1981). Some properties of time series data and their use in econometric model specification, Journal of Econometrics, 16, 121-130.

Granger, C.W.J. and Hyung, N. (2004). Occasional structural breaks and long memory with an application to the S\&P 500 absolute stock return. Journal of Empirical Finance, $11,399-421$.

Granger, C.W.J., and Joyeux, R. (1980). An introduction to long memory time series models and fractional differencing, Journal of Time Series Analysis, 1, 15-39.

Greiner, A., Köller, U., \& Semmler, W. (2004). Debt sustainability in the European Monetary Union: Theory and empirical evidence for selected countries, Oxford Economic Papers, 59(2), 194-218.

Greiner, A., \& Semmler, W. (1999). An Inquiry Into the Sustainability of German Fiscal Policy: Some Time Series Test, Public Finance Review, 27(2), 220-236.

Greiner, A., Koeller, U., \& Semmler, W. (2006). Testing the sustainability of German fiscal policy: Evidence for the period 1960-2003, Empirica, 33, 127-140.

Hakkio, G., \& Rush, M. (1991). Is the budget deficit "too large?, Economic Inquiry, 29(3), 429-445.

Hamilton, J., \& Flavin, M. (1986). On the limitations of government borrowing: A framework for empirical testing, American Economic Review, 76(4), 808-816.

Hatemi-J, A. (2002). Fiscal policy in Sweden: Effects of EMU criteria convergence, Economic Modelling, 19(1), 121-136.

Haug, A.A. (1991). Cointegration and government borrowing constraints: Evidence for the United States, Journal of Business \& Economic Statistics, 9(1), 97-101.

Haug, A.A. (1995). Has federal budget deficit policy changed in recent years? Economic Inquiry, 33, 104-118.

Hosking, J.R.M. (1981). Fractional differencing, Biometrika, 68, 165-176.

Lusinyan, L., \& Thornton, J. (2011). Unit roots, structural breaks and cointegration in the UK public finances, 1750-2004, Applied Economics, 43(20), 2583-2592. 
Marinheiro, C.F. (2006). The sustainability of Portuguese fiscal policy from a historical perspective, Empirica, 33, 155-179.

Martin, G. (2000). US deficit sustainability: A new approach based on multiple endogenous breaks, Journal of Applied Econometrics, 15(1), 83-105.

Michelacci C., Zaffaroni P. (2000). (Fractional) beta convergence, Journal of Monetary Economics, 45(1), 129-153.

Olekalns, N. (2000). Sustainability and stability? Australian fiscal policy in the twentieth century, Australian Economic Papers, 39(2), 138-151.

Paparas, D., Richter, C., \& Paparas, A. (2015). A synthesis of empirical research in the sustainability of fiscal policy, Journal of Economics Bibliography, 2(4), 164-183.

Payne, J. (1997). International evidence on the sustainability of budget deficits, Applied Economics Letters, 4(12), 775-779.

Payne, J.E., \& Mohammadi, H. (2006). Are adjustments in the U.S. budget deficit asymmetric? Another look at sustainability, Atlantic Economic Journal, 34, $15-22$.

Quintos, C. (1995). Sustainability of the deficit process with structural shifts, Journal of Business and Economic Statistics, 13(4), 409-417.

Trehan, B., \& Walsh, C. (1988). Common trends, the government's budget constraint, and revenue smoothing, Journal of Economic Dynamics and Control, 12(2-3), 425-440.

Trehan, B., \& Walsh, C.E. (1991). Testing intertemporal budget constraints: Theory and applications to US federal budget and current account deficits, Journal of Money, Credit and Banking, 23(2), 206-233.

Wilcox, D. (1989). The sustainability of government deficits: Implications of the present-value borrowing constraint, Journal of Money, Credit, and Banking, 21(3), 291-306.

Yoon, G. (2012). Explosive U.S. budget deficit, Economic Modelling, 29(4), $1076-1080$. 
Table 1: Summary of some empirical works on fiscal sustainability

\begin{tabular}{|c|c|c|c|c|c|}
\hline Author(s) & State(s) & $\begin{array}{l}\text { Time period } \\
\text { (frequency) }\end{array}$ & Variables & Tests performed & Sustainability? \\
\hline $\begin{array}{l}\text { Hamilton \& Flavin } \\
\text { (1986) }\end{array}$ & U.S. & $\begin{array}{l}\text { 1962-1984 } \\
\text { (annual) }\end{array}$ & $\begin{array}{l}\text { Deficit \& } \\
\text { debt }\end{array}$ & $\begin{array}{l}\text { - Dickey-Fuller test for unit roots } \\
\text { - Generalized Flood-Garber test } \\
\text { - Restricted Flood-Garber test }\end{array}$ & $\begin{array}{l}\text { Yes: consistent with the IBC ( at } 10 \% \\
\text { significance level) }\end{array}$ \\
\hline $\begin{array}{l}\text { Trehan \& Walsh } \\
\text { (1988) }\end{array}$ & U.S. & $\begin{array}{l}1890-1986 \\
\text { (annual) }\end{array}$ & $\begin{array}{l}\text { Deficit, tax } \\
\text { smoothing }\end{array}$ & $\begin{array}{l}\text { - Dickey-Fuller test for unit roots } \\
\text {-Engle-Granger co-integration test } \\
\text {-Stock-Watson co-integration test } \\
\text { - Barro's tax smoothing hypothesis }\end{array}$ & $\begin{array}{l}\text { Yes: consistent with IBC but not with tax } \\
\text { smoothing hypothesis. }\end{array}$ \\
\hline Wilcox (1989) & U.S. & $\begin{array}{l}\text { 1960-1984 } \\
\text { (annual) }\end{array}$ & $\begin{array}{l}\text { (Un)disco- } \\
\text { unted debt }\end{array}$ & $\begin{array}{l}\text {-Dickey-Fuller test for unit roots } \\
\text {-F-statistic test } \\
\text {-Hamilton and Flavin test }\end{array}$ & $\begin{array}{l}\text { No: Fiscal policy has not been sustainable, } \\
\text { contrary to Hamilton and Flavin (1986) }\end{array}$ \\
\hline $\begin{array}{l}\text { Hakkio \& Rush } \\
(1991)\end{array}$ & U.S. & $\begin{array}{l}\text { 1950:2-1988:4 } \\
\text { (quarterly) }\end{array}$ & Deficit & $\begin{array}{l}\text {-ADF unit roots test } \\
\text {-Different co-integration tests }\end{array}$ & $\begin{array}{l}\text { Yes: for the entire sample. } \\
\text { No: from 1976:3 to } 1988: 4\end{array}$ \\
\hline Haug (1991) & U.S. & $\begin{array}{l}\text { 1960:1-1987:4 } \\
\text { (quarterly) }\end{array}$ & $\begin{array}{l}\text { Debt (bond) } \\
\& \text { Surplus }\end{array}$ & $\begin{array}{l}\text { - The co-integration regression } \\
\text { Durbin-Watson (CRDW) test } \\
\text { - ADF unit roots test }\end{array}$ & $\begin{array}{l}\text { Yes: variables are stationary in first } \\
\text { differences; co-integration tests imply the } \\
\text { acceptance of the present value borrowing } \\
\text { constraint }\end{array}$ \\
\hline $\begin{array}{l}\text { Trehan \& Walsh } \\
\text { (1991) }\end{array}$ & U.S. & $\begin{array}{l}1960-1984 \\
1946-1987 \\
\text { (annual) }\end{array}$ & $\begin{array}{l}\text { Deficit, debt } \\
\& \text { external } \\
\text { investment }\end{array}$ & $\begin{array}{l}\cdot \text { Dickey-Fuller test for unit roots } \\
\cdot \text { Phillips' test }\end{array}$ & $\begin{array}{l}\text { Yes: for the federal government's budget, } \\
\text { the deficit is consistent with sustainability; } \\
\text { also, for the external investment. }\end{array}$ \\
\hline $\begin{array}{l}\text { Ahmed \& Rogers } \\
\text { (1995) }\end{array}$ & $\begin{array}{l}\text { U.S. \& } \\
\text { U.K. }\end{array}$ & $\begin{array}{l}1792-1992 \\
1692-1992 \\
\text { (annual) }\end{array}$ & IBC \& IBOC & $\begin{array}{l}\cdot \text { Phillips-Perron unit roots test } \\
\cdot \text { Perron unit roots test } \\
\cdot \text { ADF unit roots test } \\
\cdot \text { - Co-integration \& stability tests }\end{array}$ & $\begin{array}{l}\text { Yes: in the U.S. and U.K., both constraints } \\
\text { being satisfied in entire sample. }\end{array}$ \\
\hline Quintos (1995) & U.S. & $\begin{array}{l}\text { 1947:2-1992:3 } \\
\text { (quarterly) }\end{array}$ & $\begin{array}{l}\text { Deficit } \\
\text { (Breaks) }\end{array}$ & $\begin{array}{l}\text {-Phillips \& Ploberger (1994) PIC test } \\
\text {-ADF unit roots test } \\
\text { - Rank constancy test with breaks for } \\
\text { co-integration (Quintos, 1994) }\end{array}$ & $\begin{array}{l}\text { Yes: co-integration is a sufficient } \\
\text { condition in the 'strict' sense of } \\
\text { sustainability and holds only up to } 1980 . \\
\text { Independently of shifts, deficit is } \\
\text { sustainable. }\end{array}$ \\
\hline Crowder (1997) & U.S. & $\begin{array}{l}\text { 1950:1-1994:2 } \\
\text { (quarterly) }\end{array}$ & IBC & $\begin{array}{l}\cdot \text { ADF unit roots test } \\
\text { ·Johansen's (1994) method }\end{array}$ & $\begin{array}{l}\text { No: expenditures grow faster than } \\
\text { revenues as from 1982; this is in the line } \\
\text { of Hakkio \& Rush (1991), Wilcox (1989) } \\
\text { \& Quintos (1995) }\end{array}$ \\
\hline Payne (1997) & $\mathrm{G}-7$ & $\begin{array}{l}\text { 1949-1994 } \\
\text { (annual) }\end{array}$ & Deficit & $\begin{array}{l}\text {-ADF unit roots test } \\
\text {-Engle-Granger co-integrating } \\
\text { regressions. }\end{array}$ & $\begin{array}{l}\text { Yes: for Germany; for Canada, Italy, U.K. } \\
\text { \& the U.S., the estimated b's are } \\
\text { significantly less than one. } \\
\text { No: for France, Japan \& Italy. } \\
\text { It is contrary to Owoye (1995) }\end{array}$ \\
\hline Bohn (1998) & U.S. & $\begin{array}{l}\text { 1916-1995 } \\
\text { (annual) }\end{array}$ & $\begin{array}{l}\text { Debt \& } \\
\text { surpluses }\end{array}$ & $\begin{array}{l}\text { •Phillips-Perron test; ADF test; KPSS } \\
\text { test; different regressions. } \\
\text { •Bohn's test (relationship between } \\
\text { primary surpluses \& debt ratio) }\end{array}$ & $\begin{array}{l}\text { Yes: the debt-GDP ratio should be mean- } \\
\text { reverting. IBC holds despite the frequent } \\
\text { primary deficit. }\end{array}$ \\
\hline $\begin{array}{l}\text { Greiner \& Semmler } \\
\text { (1999) }\end{array}$ & Germany & $\begin{array}{l}\text { 1955-1994 } \\
\text { (annual) }\end{array}$ & $\begin{array}{l}\text { Discounted } \\
\text { net debt }\end{array}$ & $\begin{array}{l}\text { - Restricted Flood-Garber Test } \\
\text {-ADF test for unit roots } \\
\text {-AR(2) estimations }\end{array}$ & No: in particular, after 1989. \\
\hline Martin (2000) & U.S. & $\begin{array}{l}\text { 1947:2-1992:3 } \\
\text { (quarterly) as } \\
\text { Quintos (1995) }\end{array}$ & $\begin{array}{l}\text { Deficit } \\
\text { (Breaks) }\end{array}$ & $\begin{array}{l}\text {-Phillips \& Ploberger (1994) PIC test } \\
\text { \&ADF unit roots test based on OLS. } \\
\text {-Co-integration with endogenous } \\
\text { breaks }\end{array}$ & $\begin{array}{l}\text { Yes: over the } 1947-1992 \text { period, as in } \\
\text { Quintos (1995). It is found } 3 \text { breaks: } \\
1975: 1,1985: 1, \& 1987: 1\end{array}$ \\
\hline Olekalns (2000) & Australia & $\begin{array}{l}1900-1994 / 95 \\
\text { (annual) } \\
1978: 3-1997: 4 \\
\text { (quarterly) }\end{array}$ & $\begin{array}{l}\text { IBC } \\
\text { (Breaks) }\end{array}$ & $\begin{array}{l}\text {-ADF test } \\
\text { - KPSS test } \\
\text {-Zivot and Andrews (1992) test } \\
\text { - Engle and Granger's (1987) test } \\
\text { - Gregory-Hansen (1996) test }\end{array}$ & $\begin{array}{l}\text { No: there has not been adherence to the } \\
\text { IBC but there exist recent budget } \\
\text { surpluses; it is detected structural shifts in } \\
\text { fiscal policy at the end of World War II } \\
\text { and in the 1980s. }\end{array}$ \\
\hline $\begin{array}{l}\text { Feve \& Henin } \\
(2000)\end{array}$ & G-7 & $\begin{array}{l}\text { 1970-1999 } \\
\text { (semi-annual) }\end{array}$ & $\begin{array}{l}\text { Debt \& } \\
\text { surplus }\end{array}$ & - Feedback ADF unit root test & Yes: U.S, UK and Japan \\
\hline
\end{tabular}




\begin{tabular}{|c|c|c|c|c|c|}
\hline & & & & $\begin{array}{l}\cdot \text { ADF test } \\
\cdot \text { AR-OLS test }\end{array}$ & No: Germany, France, Italy, Canada. \\
\hline Getzner et al. (2001) & Austria & $\begin{array}{l}1960-1999 \\
\text { (annual) }\end{array}$ & $\begin{array}{l}\text { Debt \& } \\
\text { surplus }\end{array}$ & $\begin{array}{l}\text {-Generalized Flood-Garber test } \\
\text { - Restricted Flood-Garber test } \\
\text {-ADF test } \\
\text {-ARMA processes } \\
\text {-Bohn (1998) test }\end{array}$ & $\begin{array}{l}\text { Yes: stationarity from } 1960 \text { to } 1974 \text {. } \\
\text { No: non-stationarityfrom } 1975 \text { to } 1999 \text {. } \\
\text { Thus, structural break in the mid-1970s. }\end{array}$ \\
\hline Hatemi-J (2002) & Sweden & $\begin{array}{l}\text { 1963:1-2000:1 } \\
\text { (quarterly) }\end{array}$ & $\begin{array}{l}\text { Taxes \& } \\
\text { spending }\end{array}$ & $\begin{array}{l}\cdot \text { KPSS test } \\
\text {-Perron (1989) test } \\
\text {-Johansen's VAR } \\
\text {-Augmented Granger causality tests }\end{array}$ & $\begin{array}{l}\text { Yes: consistent with the IBC and feasible } \\
\text { with respect to the EMU criteria (bi- } \\
\text { directional causality) }\end{array}$ \\
\hline $\begin{array}{l}\text { Bravo \& Silvestre } \\
(2002)\end{array}$ & 11-EU & $\begin{array}{l}\text { 1960-2000 } \\
\text { (annual) }\end{array}$ & $\begin{array}{l}\text { Expenditures } \\
\text { \& revenues }\end{array}$ & $\begin{array}{l}\text {-Dickey- Fuller stationarity tests } \\
\text {-Engle- Granger cointegration test } \\
\text {-Johansen cointegration trace test } \\
\text {-The } t \text {-statistic test }(\mathrm{b}=1)\end{array}$ & $\begin{array}{l}\text { Yes: in Austria, France, Germany, } \\
\text { Netherlands and the UK. } \\
\text { No: in Belgian, Denmark, Ireland, } \\
\text { Portugal, Italy \& Finland. }\end{array}$ \\
\hline Cunado et al. (2004) & U.S. & $\begin{array}{l}\text { 1947:2-2003:1 } \\
\text { (quarterly) }\end{array}$ & $\begin{array}{l}\text { Deficit } \\
\text { (Breaks) }\end{array}$ & $\begin{array}{l}\text { Fractional processes with breaks: } \\
\text { - Robinson (1994) Lagrange Multiplier } \\
\text { (LM) test } \\
\text {-Quasi Maximum Likelihood Estimate } \\
\text { of Robinson (1995) test (QMLE) }\end{array}$ & $\begin{array}{l}\text { Yes: fiscal deficit is mean reverting } \\
\text { (an } \mathrm{I}(\mathrm{d}) \text { process with } \mathrm{d}<1 \text { ) taking into } \\
\text { account a break in the mid-1970s. }\end{array}$ \\
\hline Arestis et al. (2004) & U.S. & $\begin{array}{l}\text { 1947:2-2002:1 } \\
\text { (quarterly) }\end{array}$ & $\begin{array}{l}\text { Surplus } \\
\text { (Breaks) }\end{array}$ & $\begin{array}{l}\text {-Threshold Autoregressive (TAR) } \\
\text { model by Caner \& Hansen (2001) }\end{array}$ & $\begin{array}{l}\text { Yes: in the long run. Intervention to } \\
\text { reduce the deficit only when a certain } \\
\text { threshold }(-0.313) \text { is reached. }\end{array}$ \\
\hline $\begin{array}{l}\text { Bajo-Rubio et al. } \\
\text { (2004) }\end{array}$ & Spain & $\begin{array}{l}\text { 1964-2001 } \\
\text { (annual) }\end{array}$ & Surplus & $\begin{array}{l}\text { - Threshold Autoregressive (TAR) } \\
\text { model by Caner \& Hansen (2001) }\end{array}$ & $\begin{array}{l}\text { Yes: evidence of mean-reverting of } \\
\text { deficit once a threshold }(-1.90) \text { is reached. }\end{array}$ \\
\hline Greiner et al. (2004) & 4-EMU & $\begin{array}{l}\text { 1960-2003 } \\
\text { (annual) }\end{array}$ & $\begin{array}{l}\text { Debt \& } \\
\text { surplus }\end{array}$ & $\begin{array}{l}\text {-Bohn's (1998) test } \\
\text { •OLS estimations }\end{array}$ & $\begin{array}{l}\text { Yes: for all economies (France } \\
\text { Germany, Italy \& Portugal) }\end{array}$ \\
\hline Bohn (2005) & U.S. & $\begin{array}{l}\text { 1792-2003 } \\
\text { (annual) }\end{array}$ & $\begin{array}{l}\text { Debt \& } \\
\text { deficit }\end{array}$ & $\begin{array}{l}\cdot \text { ADF test; PP test; \& KPSS test. } \\
\text { - Regression specification obtained } \\
\text { from tax smoothing theories. }\end{array}$ & $\begin{array}{l}\text { Yes: robust positive response of primary } \\
\text { surpluses to fluctuations in the debt-GDP } \\
\text { ratio. Link with economic growth. }\end{array}$ \\
\hline Afonso (2005) & 15-EU & $\begin{array}{l}\text { 1970-2003 } \\
\text { (annual) }\end{array}$ & $\begin{array}{l}\text { Debt } \\
\text { (Breaks) }\end{array}$ & $\begin{array}{l}\text {-ADF and PP test } \\
\text { - Zivot and Andrews's (1992) test } \\
\text {-Engle-Granger and Johansen } \\
\text { cointegration tests } \\
\text { - Gregory and Hansen (1996) } \\
\text { cointegration test (regime shift) }\end{array}$ & $\begin{array}{l}\text { No, for the majority of EU- } 15 \text { countries, } \\
\text { despite of signs of stabilizing of debt-to- } \\
\text { GDP ratio at the end of the } 1990 \text { s. Only } \\
\text { Germany, the Netherlands, Finland, } \\
\text { Austria, and the U.K show signs of } \\
\text { sustainability. }\end{array}$ \\
\hline $\begin{array}{l}\text { Payne \& } \\
\text { Mohammadi (2006) }\end{array}$ & U.S. & $\begin{array}{l}\text { 1947:1-2003:4 } \\
\text { (quarterly) }\end{array}$ & $\begin{array}{l}\text { Deficit } \\
\text { (Breaks) }\end{array}$ & $\begin{array}{l}\cdot \text { TAR model } \\
\cdot \text { Momentum TAR model (MTAR) }\end{array}$ & $\begin{array}{l}\text { Yes: allowing for an endogenously } \\
\text { structural break in 1982:1. } \\
\text { Deficit shows symmetric mean-reverting } \\
\text { behaviour around the threshold value. }\end{array}$ \\
\hline $\begin{array}{l}\text { Bajo-Rubio et al. } \\
(2006)\end{array}$ & Spain & $\begin{array}{l}1964-2003 \\
\text { (annual) } \\
\text { 1982:1-2004:1 } \\
\text { (quarterly) }\end{array}$ & $\begin{array}{l}\text { Expenditures } \\
\& \text { revenues }\end{array}$ & $\begin{array}{l}\cdot \mathrm{Ng}-\text { Perron }(2001) \text { tests of unit roots } \\
\cdot \text { Hansen-Seo (2002) tests of threshold } \\
\text { cointegration }\end{array}$ & $\begin{array}{l}\text { Yes: mean-reverting dynamic behaviour } \\
\text { after threshold: } 5.30 \% \text { of GDP for annual } \\
\text { data and } 7 \% \text {, for quarterly data. The main } \\
\text { consolidation effort was at the end of the } \\
\text { first half of the } 80 \text { s, and } 1993-95 \text {. }\end{array}$ \\
\hline Marinheiro (2006) & Portugal & $\begin{array}{l}1852-2003 \\
\text { (annual) }\end{array}$ & $\begin{array}{l}\text { Debt \& } \\
\text { deficit } \\
\text { (Breaks) }\end{array}$ & $\begin{array}{l}\text {-ADF test; PP test; \& KPSS test. } \\
\text {-Engle and Granger test } \\
\text { - Johansen maximum likelihood test } \\
\text { - Gregory and Hansen test }\end{array}$ & $\begin{array}{l}\text { Yes: for } 1903-2003 \text {. } \\
\text { No: for } 1975-2003 \text {. } \\
\text { Fiscal policy is unsustainable since } 1975 \text {. }\end{array}$ \\
\hline Greiner et al. (2006) & Germany & $\begin{array}{l}\text { 1960-2003 } \\
\text { (annual) }\end{array}$ & $\begin{array}{l}\text { Debt \& } \\
\text { Surplus }\end{array}$ & $\begin{array}{l}\text {-Semi-parametric regressions with } \\
\text { time depending coefficients as an } \\
\text { extension of Bohn's (1998) approach. }\end{array}$ & $\begin{array}{l}\text { Yes: public debt is sustainable as in } \\
\text { Greiner et al. (2004). }\end{array}$ \\
\hline $\begin{array}{l}\text { Argyrou \& Luintel } \\
(2007)\end{array}$ & $\begin{array}{l}\text { 4-EMU: } \\
\text { Greece } \\
\text { Italy } \\
\text { Ireland \& } \\
\text { Netherland }\end{array}$ & $\begin{array}{l}1970: 1-1998: 3 \\
1962: 2-1997: 4 \\
1957: 1-1998: 4 \\
\text { (quarterly) }\end{array}$ & $\begin{array}{l}\text { Expenditures } \\
\& \text { revenues } \\
\text { (Breaks) }\end{array}$ & $\begin{array}{l}\cdot \text { DOLS and DGLS estimators of the } \\
\text { co-integrating vector. } \\
\text {-Tests for non-linear fiscal } \\
\text { adjustment }\end{array}$ & $\begin{array}{l}\text { Yes: for all } 4 \text { economies, across different } \\
\text { time horizons (Maastricht effect) }\end{array}$ \\
\hline Correia et al. (2008) & Portugal & $\begin{array}{l}\text { 1852-2004 } \\
\text { (annual) }\end{array}$ & $\begin{array}{l}\text { Expenditures } \\
\& \text { revenues } \\
\text { (Breaks) }\end{array}$ & $\begin{array}{l}\text {-ADF test \& PP test. } \\
\text { - Cointegration tests (Johansen \& } \\
\text { Saikkonen and Lütkepohl) } \\
\text {-Breitung's non-parametric test }\end{array}$ & $\begin{array}{l}\text { Yes: for } 1923-1973 \text { and since } 1986 . \\
\text { No: for } 1852-1922 \text { and } 1974-1985 \text {. } \\
\text { Breitung test and the Bohn test (based on }\end{array}$ \\
\hline
\end{tabular}




\begin{tabular}{|c|c|c|c|c|c|}
\hline & & & & $\cdot$ Bohn's test & $\begin{array}{l}\text { theoretical model) are useful to detecting } \\
\text { unsustainability. }\end{array}$ \\
\hline $\begin{array}{l}\text { Cipollini et al. } \\
(2009)\end{array}$ & U.S. & $\begin{array}{l}\text { 1947:1-2004:4 } \\
\text { (quarterly) }\end{array}$ & $\begin{array}{l}\text { Expenditures } \\
\& \text { revenues } \\
\text { (Breaks) }\end{array}$ & $\begin{array}{l}\text {-ADF test \& PP test. } \\
\cdot \text { Ng \& Perron (2001) under GLS } \\
\text { - Lagrange multiplier threshold test. } \\
\text { - Berkowitz (2001) test }\end{array}$ & $\begin{array}{l}\text { Yes: in the long run. Intervention to reduce } \\
\text { the deficit only when a threshold ( } \$ 8.859 \\
\text { per capita) is reached. Fiscal adjustments } \\
\text { take place via spending cuts. Major shifts: } \\
\text { feb-1975, mar-1981, feb-1999 }\end{array}$ \\
\hline $\begin{array}{l}\text { Berenguer-Rico \& } \\
\text { Carrion-i-Silvestre } \\
(2011)\end{array}$ & U.S. & $\begin{array}{l}\text { 1947:1-2007:3 } \\
\text { (quarterly) as in } \\
\text { Quintos (1995), } \\
\text { Martin (2000) \& } \\
\text { Cunado et al., } \\
\text { (2004) }\end{array}$ & $\begin{array}{l}\text { Debt \& } \\
\text { deficit } \\
\text { (Breaks) } \\
\text { Unified } \\
\text { framework }\end{array}$ & $\begin{array}{l}\text {-Perron-Yabu (2009) test } \\
\text { - Gregory and Hansen test } \\
\text { - Carrion-i-Silvestre and Sansó test. } \\
\text {-Estimation of the multicointegration } \\
\text { and } \mathrm{I}(2) \text { cointegration regressions }\end{array}$ & $\begin{array}{l}\text { Yes: there is a long-run stock-flow } \\
\text { relationship between revenues and } \\
\text { expenditures with one break by the mid- } \\
\text { 1990s (1995:4 or } 1996: 4 \text {, depending on } \\
\text { the model) }\end{array}$ \\
\hline $\begin{array}{l}\text { Lusinyan \& } \\
\text { Thornton (2011) }\end{array}$ & U.K. & $\begin{array}{l}1750-2004 \\
\text { (annual) as in } \\
\text { Ahmed \& } \\
\text { Rogers (1995). }\end{array}$ & $\begin{array}{l}\text { Expenditures } \\
\& \text { revenues } \\
\text { (Breaks) }\end{array}$ & $\begin{array}{l}\text {-Different unit roots tests. } \\
\text {-Different cointegration tests: } \\
\text {-Gregory and Hansen }(1996) \text { test } \\
\text {-Johansen }(1988,1991,1995) \text { test } \\
\text {-Johansen et al., (2000) test }\end{array}$ & $\begin{array}{l}\text { Yes: strong evidence of a long-run } \\
\text { relationship between revenues and } \\
\text { expenditures; some of the main } \\
\text { breakpoints are linked to war events. }\end{array}$ \\
\hline Yoon (2012) & U.S. & $\begin{array}{l}\text { 1947:1-2007:3 } \\
\text { (quarterly) as in } \\
\text { Berenguer-Rico } \\
\text { \& Carrion-i- } \\
\text { Silvestre (2011) }\end{array}$ & $\begin{array}{l}\text { Deficit } \\
\text { (Breaks) }\end{array}$ & $\begin{array}{l}\text {-ADF test } \\
\text { - Recursive ADF test suggested by } \\
\text { Phillips et al. (2011) for explosiveness }\end{array}$ & $\begin{array}{l}\text { Yes: the post-war U.S. budget deficit } \\
\text { was explosive. This work should be } \\
\text { studied again taking into account a new } \\
\text { version of recursive test for multiple } \\
\text { episodes of explosiveness. }\end{array}$ \\
\hline $\begin{array}{l}\text { Fan \& Arghyrou } \\
(2012)\end{array}$ & U.K. & $\begin{array}{l}\text { 1955:1-2006:1 } \\
\text { (quarterly) }\end{array}$ & $\begin{array}{l}\text { Expenditures } \\
\& \text { revenues } \\
\text { (Breaks) }\end{array}$ & $\begin{array}{l}\cdot \text { ADF test and PP test. } \\
\cdot \text { DOLS and DGLS estimators of the } \\
\text { co-integrating vector. } \\
\cdot \text { ECM estimations } \\
\cdot \text { Bai \& Perron (1998) test. } \\
\cdot \text { QL-STECM test }\end{array}$ & $\begin{array}{l}\text { Yes: for the full time sample and } \\
\text { subperiods identified, with } 3 \text { breaks in the } \\
\text { early } 1970 \text { s \& } 1980 \text { s and late } 1990 \text { s. } \\
\text { No: from } 1973 \text { to } 1981 \text {. }\end{array}$ \\
\hline $\begin{array}{l}\text { Cuestas \& Staehr } \\
\text { (2013) }\end{array}$ & $\begin{array}{l}10-\text {-EU } \\
(\text { Central \& } \\
\text { Eastern })\end{array}$ & $\begin{array}{l}\text { 1999:1 -2010:2 } \\
\text { (quarterly) }\end{array}$ & $\begin{array}{l}\text { Budget } \\
\text { balance in \% } \\
\text { of GDP } \\
\text { (Breaks) }\end{array}$ & $\begin{array}{l}\cdot \mathrm{Ng}-\text { Perron }(2001), \mathrm{KSS} \& \text { Sollis } \\
(2009) \text { unit root test. } \\
\cdot \text { Lee \& Strazicich (2003) unit root test }\end{array}$ & $\begin{array}{l}\text { Yes: in the long run, the series seem to be } \\
\text { mean-reverting, after controlling for } \\
\text { structural changes, but they also exhibit } \\
\text { instability. }\end{array}$ \\
\hline $\begin{array}{l}\text { Bajo-Rubio et al. } \\
(2014)\end{array}$ & Spain & $\begin{array}{l}\text { 1850-2000 } \\
\text { (annual) }\end{array}$ & $\begin{array}{l}\text { Debt, surplus, } \\
\text { expenditures } \\
\& \text { revenues }\end{array}$ & $\begin{array}{l}\cdot \mathrm{Ng}-\text { Perron tests for unit roots. } \\
\cdot \text { Sims-Stock-Watson (1990) tests for } \\
\text { Granger-causality. } \\
\text {-The impulse-response functions. }\end{array}$ & $\begin{array}{l}\text { Yes: from } 1850 \text { to } 2000 \text {. Intervention is } \\
\text { needed if the deficit is over a threshold } \\
\text { (around } 4.5 \% \text { of GDP, according to Bajo- } \\
\text { Rubio et al., 2010). The resuts support } \\
\text { Escario et al. (2012); Tortella (2000) or } \\
\text { Comín (1995, 1996). }\end{array}$ \\
\hline Chen (2014) & $\begin{array}{l}\text { G-7 \& } \\
\text { Greece, } \\
\text { Ireland, } \\
\text { Portugal } \\
\text { \& Spain }\end{array}$ & $\begin{array}{l}\text { 1980:1-2012:4 } \\
\text { (quarterly) }\end{array}$ & $\begin{array}{l}\text { Debt } \\
\text { imbalance }\end{array}$ & $\begin{array}{l}\text {-Linear unit root tests. } \\
\text {-TAR and MTAR unit root tests. } \\
\text {-LSTR-TAR and LSTR-MTAR unit } \\
\text { root tests. }\end{array}$ & Yes: in the long run (for TAR and MTAR) \\
\hline $\begin{array}{l}\text { Afonso \& Tovar } \\
\text { (2017) }\end{array}$ & 11-EMU & $\begin{array}{l}\text { 1999:1-2013:4 } \\
\text { (quarterly) }\end{array}$ & $\begin{array}{l}\text { Debt \& } \\
\text { surplus }\end{array}$ & $\begin{array}{l}\text {-Different unit root tests. } \\
\text {-Johansen-Juselius cointegration test. } \\
\text {-Stock-Watson-Shins test. } \\
\text {-Toda \& Yamamoto (1995) for } \\
\text { Granger causality test. } \\
\text {-Impulse response functions } \\
\end{array}$ & $\begin{array}{l}\text { Yes: in Belgium, France, Germany, \& the } \\
\text { Netherlands. Strong importance of } \\
\text { expenditure-based fiscal rules }\end{array}$ \\
\hline \multicolumn{6}{|c|}{$\begin{array}{l}\text { Notes: } \\
\text {-Intertemporal Government Budget Constraint (IBC) } \\
\text {-Intertemporal External Borrowing Constraints (IBOC) } \\
\text {-EMU: European Monetary Union } \\
\text {-ADF test: Augmented Dickey-Fuller (1981) test for the null hypothesis of a unit root. } \\
\text {-PP test: Phillips and Perron (1988) test for the null hypothesis of non-stationarity. } \\
\text {-KPSS test: Kwiatowski et al. (1992) test for stationarity. } \\
\text {-KSS: Kapetanios, Shin, and Snell (2003) for unit root in the nonlinear STAR framework } \\
\text {-Zivot-Andrews (1992) tests for the null hypothesis of a unit root (and exogenous change) } \\
\text {-Engle-Granger (1987) test of the null hypothesis of no cointegration } \\
\text {-Johansen (1988) maximum likelihood (LM) test } \\
\text {-Gregory and Hansen (1996) test specifies the null hypothesis of non-cointegration } \\
\text {-Carrion-i-Silvestre and Sansó (2006) test, the null is cointegration with one structural break. } \\
\text {-DOLS: Dynamic Ordinary Least Square } \\
\text {-DGLS: Generalized Least Squares } \\
\text {-QL-STECM: quadratic-logistic smooth threshold error correction model }\end{array}$} \\
\hline
\end{tabular}


Table 2: Estimates of $d$ and $95 \%$ confidence band on Expenditure/GDP ratio

\begin{tabular}{|c|c|c|c|}
\hline Country & No regressors & An intercept & A linear trend \\
\hline U. K. & $0.94(0.82,1.10)$ & $0.64(0.56,0.76)$ & $0.62(0.52,0.75)$ \\
\hline AUSTRIA & $0.94 \quad(0.78,1.17)$ & $0.06 \quad(-0.07,0.26)$ & $0.07 \quad(-0.07,0.27)$ \\
\hline BELGIUM & $0.97 \quad(0.84,1.14)$ & $0.42 \quad(0.35,0.53)$ & $0.42 \quad(0.35,0.53)$ \\
\hline BULGARIA & $0.89 \quad(0.74,1.11)$ & $-0.07(-0.20,0.12)$ & $-0.16-(-0.31,0.07)$ \\
\hline CYPRUS & $0.82 \quad(0.70,0.98)$ & $0.12(0.04,0.23)$ & $-0.29^{+}(-0.40,-0.12)$ \\
\hline CZECH REP. & $0.92 \quad(0.77,1.14)$ & $0.09 \quad(-0.04,0.25)$ & $0.08 \quad(-0.05,0.26)$ \\
\hline DENMARK & $0.93(0.78,1.16)$ & $0.49 \quad(0.38,0.63)$ & $0.46 \quad(0.34,0.62)$ \\
\hline ESTONIA & $0.90 \quad(0.75,1.12)$ & $0.36 \quad(0.26,0.50)$ & $0.33 \quad(0.21,0.49)$ \\
\hline FINLAND & $0.93 \quad(0.78,1.14)$ & $0.69 \quad(0.58,0.87)$ & $0.66 \quad(0.52,0.86)$ \\
\hline FRANCE & $0.96(0.84,1.13)$ & $0.70 \quad(0.58,0.85)$ & $0.71^{+}(0.60,0.86)$ \\
\hline GERMANY & $0.87 \quad(0.74,1.05)$ & $0.11(0.01,0.24)$ & $0.05^{-}(-0.09,0.31)$ \\
\hline GREECE & $0.87 \quad(0.72,1.08)$ & $0.21 \quad(0.12,0.33)$ & $\mathrm{0.03}^{+}(-0.08,0.18)$ \\
\hline HUNGARY & $0.93 \quad(0.77,1.16)$ & $-0.11(-0.23,0.11)$ & $-0.16^{+}(-0.31,0.07)$ \\
\hline IRELAND & $0.90 \quad(0.73,1.14)$ & $0.44 \quad(0.36,0.56)$ & $\mathbf{0 . 3 3}^{+}(0.19,0.51)$ \\
\hline ITALY & $0.90 \quad(0.75,1.11)$ & $-0.06(-0.16,0.08)$ & $-0.50+(-0.63,-0.31)$ \\
\hline LATVIA & $0.89 \quad(0.74,1.11)$ & $0.16(0.05,0.31)$ & $0.15 \quad(0.02,0.32)$ \\
\hline LITHUANIA & $0.90 \quad(0.74,1.13)$ & $0.25(0.14,0.41)$ & $0.26 \quad(0.14,0.42)$ \\
\hline LUXEMBOURG & $0.92 \quad(0.76,1.14)$ & $0.24 \quad(0.11,0.45)$ & $0.15^{+} \quad(-0.02,0.41)$ \\
\hline MALTA & $0.89 \quad(0.73,1.11)$ & $-0.16(-0.30,0.04)$ & $-0.14 \quad(-0.28,0.06)$ \\
\hline NETHERLANDS & $0.93 \quad(0.77,1.16)$ & $0.48 \quad(0.39,0.54)$ & $0.38^{+}(0.24,0.55)$ \\
\hline POLAND & $0.91 \quad(0.76,1.14)$ & $0.18 \quad(-0.01,0.45)$ & $0.20 \quad(0.01,0.49)$ \\
\hline PORTUGAL & $0.90 \quad(0.76,1.12)$ & $0.12(0.04,0.24)$ & $-0.24^{+}(-0.38,-0.04)$ \\
\hline ROMANIA & $0.93 \quad(0.76,1.17)$ & $0.12 \quad(-0.01,0.36)$ & $0.11 \quad(-0.03,0.36)$ \\
\hline SLOVAK REP. & $0.93 \quad(0.78,1.14)$ & $0.40 \quad(0.31,0.54)$ & $0.36-(0.25,0.52)$ \\
\hline SLOVENIA & $0.87 \quad(0.72,1.05)$ & $0.23 \quad(0.12,0.38)$ & $0.19^{+}(0.08,0.34)$ \\
\hline SPAIN & $0.88 \quad(0.75,1.06)$ & $0.16(0.09,0.27)$ & $0.13 \quad(0.04,0.24)$ \\
\hline SWEDEN & $0.94 \quad(0.81,1.12)$ & $0.41 \quad(0.29,0.57)$ & $0.42^{-}(0.29,0.60)$ \\
\hline
\end{tabular}

In bold the significant models according to the deterministic terms. $+/$ - in the last column indicates significant positive/negative trend coefficients. 
Table 3: Estimates of $d$ and $95 \%$ confidence band on Revenues/GDP ratio

\begin{tabular}{|c|c|c|c|}
\hline Country & No regressors & An intercept & A linear trend \\
\hline U. K. & $0.93 \quad(0.83,1.07)$ & $0.10 \quad(0.04,0.18)$ & $0_{0.03}^{+}(-0.04,0.13)$ \\
\hline AUSTRIA & $0.90 \quad(0.75,1.11)$ & $-0.18(-0.26,-0.08)$ & $-0.28 \quad(-0.39,-0.16)$ \\
\hline BELGIUM & $0.88 \quad(0.78,1.03)$ & $-0.38(-0.44,-0.31)$ & $-0.47^{+}(-0.53,-0.40)$ \\
\hline BULGARIA & $0.97 \quad(0.80,1.22)$ & $0.11(-0.01,0.30)$ & $-0.18^{-} \quad(-0.36,0.13)$ \\
\hline CYPRUS & $0.88 \quad(0.75,1.06)$ & $0.222(0.14,0.32)$ & $-0.01^{+}(-0.10,0.15)$ \\
\hline CZECH REP. & $0.93 \quad(0.77,1.15)$ & $0.03(-0.11,0.22)$ & $0.03 \quad(-0.10,0.21)$ \\
\hline DENMARK & $0.93 \quad(0.75,1.16)$ & $0.12 \quad(-0.05,0.39)$ & $0.12(-0.05,0.41)$ \\
\hline ESTONIA & $0.91 \quad(0.75,1.13)$ & $0.22 \quad(0.12,0.36)$ & $\mathrm{0.08}^{+}(-0.06,0.28)$ \\
\hline FINLAND & $0.96(0.79,1.19)$ & $-0.18(-0.31,0.06)$ & $-0.18 \quad(-0.31,0.05)$ \\
\hline FRANCE & $0.93(0.81,1.10)$ & $-0.12(-0.20,-0.04)$ & $-0.24^{+}(-0.31,-0.13)$ \\
\hline GERMANY & $0.94 \quad(0.80,1.13)$ & $-0.06(-0.12,0.03)$ & $-0.16^{-}(-0.23,-0.05)$ \\
\hline GREECE & $0.88 \quad(0.74,1.08)$ & $0.23 \quad(0.14,0.37)$ & $0.23 \quad(0.13,0.37)$ \\
\hline HUNGARY & $0.92 \quad(0.76,1.14)$ & $0.11 \quad(0.01,0.26)$ & $-0.06^{+}(-0.19,0.15)$ \\
\hline IRELAND & $0.96(0.78,1.22)$ & $-0.29(-0.42,-0.09)$ & $-0.30 \quad(-0.44,-0.09)$ \\
\hline ITALY & $0.87 \quad(0.73,1.07)$ & $-0.22(-0.31,-0.12)$ & $-0.47^{+}(-0.57,-0.34)$ \\
\hline LATVIA & $0.94 \quad(0.78,1.18)$ & $0.13 \quad(-0.02,0.35)$ & $0.13 \quad(-0.02,0.36)$ \\
\hline LITHUANIA & $0.93 \quad(0.76,1.15)$ & $0.21 \quad(0.09,0.37)$ & $\left.\begin{array}{lll}0.23 & (0.11, & 0.39\end{array}\right)$ \\
\hline LUXEMBOURG & $0.94 \quad(0.78,1.16)$ & $0.09(-0.03,0.26)$ & $0.09 \quad(-0.03,0.26)$ \\
\hline MALTA & $0.89(0.73,1.10)$ & $0.03(-0.08,0.17)$ & $-0.08^{+}(-0.18,0.08)$ \\
\hline NETHERLANDS & $0.95 \quad(0.78,1.19)$ & $-0.12 \quad(-0.11,0.11)$ & $-0.12^{+}(-0.23,0.03)$ \\
\hline POLAND & $1.06(0.87,1.35)$ & $-0.22(-0.47,0.34)$ & $-0.21 \quad(-0.51,0.44)$ \\
\hline PORTUGAL & $0.88 \quad(0.73,1.09)$ & $-0.10(-0.19,0.03)$ & $-0.51^{+}(-0.64,-0.33)$ \\
\hline ROMANIA & $0.93 \quad(0.76,1.17)$ & $-0.50(-0.66,-0.22)$ & $-0.50 \quad(-0.66,-0.22)$ \\
\hline SLOVAK REP. & $0.92 \quad(0.77,1.13)$ & $0.38 \quad(0.30,0.50)$ & $0.32^{-} \quad(0.20,0.47)$ \\
\hline SLOVENIA & $0.92 \quad(0.76,1.13)$ & $0.02 \quad(-0.10,0.18)$ & $0.01 \quad(-0.10,0.15)$ \\
\hline SPAIN & $0.95 \quad(0.82,1.15)$ & $0.01(-0.11,0.20)$ & $0.00 \quad(-0.12,0.20)$ \\
\hline SWEDEN & $0.95 \quad(0.83,1.13)$ & $0.71(0.60,0.85)$ & $0.71 \quad(0.62,0.85)$ \\
\hline
\end{tabular}

In bold the significant models according to the deterministic terms. $+/$ - in the last column indicates significant positive/negative trend coefficients. 
Table 4: Estimates of $d$ and $95 \%$ bands on Expenditures - Revenues (in logs)

\begin{tabular}{|c|c|c|c|}
\hline Country & No regressors & An intercept & A linear trend \\
\hline U. K. & $0.41 \quad(0.34,0.51)$ & $0.42 \quad(0.35,0.52)$ & $0.41 \quad(0.34,0.51)$ \\
\hline AUSTRIA & $-0.09(-0.16,0.02)$ & $-0.13(-0.24,0.02)$ & $-0.25^{+}(-0.41,-0.04)$ \\
\hline BELGIUM & $-0.05(-0.12,0.04)$ & $-0.04(-0.09,0.03)$ & $-0.06^{-}(-0.11,0.01)$ \\
\hline BULGARIA & $-0.05(-0.18,0.15)$ & $-0.05(-0.18,0.15)$ & $-0.10(-0.23,0.11)$ \\
\hline CYPRUS & $0.13 \quad(0.02,0.27)$ & $0.13 \quad(0.02,0.27)$ & $0.13 \quad(0.02,0.27)$ \\
\hline CZECH REP. & $0.21 \quad(0.02,0.43)$ & $0.16 \quad(0.01,0.37)$ & $0.13 \quad(-0.04,0.35)$ \\
\hline DENMARK & $0.60 \quad(0.49,0.75)$ & $0.58 \quad(0.48,0.72)$ & $0.57 \quad(0.46,0.72)$ \\
\hline ESTONIA & $0.09 \quad(-0.05,0.32)$ & $0.09 \quad(-0.06,0.32)$ & $0.10 \quad(-0.06,0.33)$ \\
\hline FINLAND & $0.31 \quad(0.18,0.53)$ & $0.29 \quad(0.17,0.50)$ & $0^{0.16}{ }^{+}(0.02,0.44)$ \\
\hline FRANCE & $0.01 \quad(-0.07,0.10)$ & $0.01(-0.06,0.09)$ & $0.00(-0.06,0.09)$ \\
\hline GERMANY & $0.10 \quad(0.05,0.27)$ & $0.08 \quad(0.04,0.23)$ & $0.12^{-} \quad(-0.03,0.36)$ \\
\hline GREECE & $0.14 \quad(0.06,0.29)$ & $0.23 \quad(0.11,0.41)$ & $0.01^{+}(0.22,0.31)$ \\
\hline HUNGARY & $0.18 \quad(0.05,0.37)$ & $0.16 \quad(0.05,0.33)$ & $0.10 \quad(-0.03,0.30)$ \\
\hline IRELAND & $0.43 \quad(0.32,0.57)$ & $0.43 \quad(0.34,0.55)$ & $0^{0.32} 2^{+}(0.19,0.50)$ \\
\hline ITALY & $-0.11(-0.16,-0.03)$ & $-0.24(-0.35,-0.07)$ & $-0.29^{+}(-0.43,-0.10)$ \\
\hline LATVIA & $0.07 \quad(-0.04,0.24)$ & $0.08(-0.04,0.24)$ & $0.06(-0.07,0.24)$ \\
\hline LITHUANIA & $0.27 \quad(0.16,0.43)$ & $0.29 \quad(0.18,0.44)$ & $0.26 \quad(0.13,0.43)$ \\
\hline LUXEMBOURG & $0.24 \quad(0.11,0.42)$ & $0.21 \quad(0.09,0.37)$ & $0.09^{+}(-0.06,0.30)$ \\
\hline MALTA & $0.19 \quad(0.03,0.37)$ & $0.11 \quad(0.00,0.23)$ & $-0.04^{-} \quad(-0.16,0.12)$ \\
\hline NETHERLANDS & $0.31 \quad(0.18,0.52)$ & $0.34 \quad(0.21,0.55)$ & $0.26^{+}(0.09,0.51)$ \\
\hline POLAND & $0.01 \quad(-0.11,0.29)$ & $0.01 \quad(-0.25,0.39)$ & $0.07 \quad(-0.23,0.51)$ \\
\hline PORTUGAL & $0.08 \quad(0.00,0.24)$ & $0.12(0.00,0.30)$ & $\mathrm{0.06}^{+}(-0.11,0.27)$ \\
\hline ROMANIA & $0.20 \quad(0.09,0.37)$ & $0.21 \quad(0.10,0.38)$ & $0.20 \quad(0.08,0.38)$ \\
\hline SLOVAK REP. & $0.58 \quad(0.43,0.78)$ & $0.47 \quad(0.33,0.70)$ & $0.47 \quad(0.32,0.70)$ \\
\hline SLOVENIA & $0.21 \quad(0.09,0.36)$ & $0.21 \quad(0.09,0.36)$ & $0.17^{+}(0.05,0.32)$ \\
\hline SPAIN & $0.36 \quad(0.28,0.45)$ & $0.37 \quad(0.31,0.46)$ & $0.36 \quad(0.28,0.45)$ \\
\hline SWEDEN & $0.69 \quad(0.58,0.86)$ & $0.60 \quad(0.50,0.77)$ & $0.62^{-} \quad(0.52,0.79)$ \\
\hline
\end{tabular}

In bold the significant models according to the deterministic terms. $+/$ - in the last column indicates significant positive/negative trend coefficients. 
Table 5: Summary estimates of $d$ for the three series

\begin{tabular}{|c|c|c|c|}
\hline Country & Exp / GDP & Rev / GDP & Exp - Rev \\
\hline U. K. & $0.64 \quad(0.56,0.76)$ & $0.03^{+}(-0.04,0.13)$ & $0.42(0.35,0.52)$ \\
\hline AUSTRIA & $0.06 \quad(-0.07,0.26)$ & $-0.28(-0.39,-0.16)$ & $-0.25(-0.41,-0.04)$ \\
\hline BELGIUM & $0.42(0.35,0.53)$ & $-0.47(-0.53,-0.40)$ & $-0.06(-0.11,0.01)$ \\
\hline BULGARIA & $-0.16(-0.31,0.07)$ & $-0.18 \quad(-0.36,0.13)$ & $-0.05(-0.18,0.15)$ \\
\hline CYPRUS & $-0.29(-0.40,-0.12)$ & $-0.01(-0.10,0.15)$ & $0.13(0.02,0.27)$ \\
\hline CZECH REP. & $0.09(-0.04,0.25)$ & $0.03 \quad(-0.11,0.22)$ & $0.16(0.01,0.37)$ \\
\hline DENMARK & $0.49(0.38,0.63)$ & $0.12 \quad(-0.05,0.39)$ & $0.60 \quad(0.49,0.75)$ \\
\hline ESTONIA & $0.36 \quad(0.26,0.50)$ & $0.08(-0.06,0.28)$ & $0.09 \quad(-0.05,0.32)$ \\
\hline FINLAND & $0.69 \quad(0.58,0.87)$ & $-0.18(-0.31,0.06)$ & $0.16 \quad(0.02,0.44)$ \\
\hline FRANCE & $0.71(0.60,0.86)$ & $-0.24(-0.31,-0.13)$ & $0.01 \quad(-0.06,0.09)$ \\
\hline GERMANY & $0.05(-0.09,0.31)$ & $-0.16(-0.23,-0.05)$ & $0.12(-0.03,0.36)$ \\
\hline GREECE & $0.03(-0.08,0.18)$ & $0.23(0.14,0.37)$ & $0.01 \quad(0.22,0.31)$ \\
\hline HUNGARY & $-0.16(-0.31,0.07)$ & $-0.06(-0.19,0.15)$ & $0.16 \quad(0.05,0.33)$ \\
\hline IRELAND & $0.33(0.19,0.51)$ & $-0.29(-0.42,-0.09)$ & $0.32(0.19,0.50)$ \\
\hline ITALY & $-0.50(-0.63,-0.31)$ & $-0.47(-0.57,-0.34)$ & $-0.29(-0.43,-0.10)$ \\
\hline LATVIA & $0.16 \quad(0.05,0.31)$ & $0.13 \quad(-0.02,0.35)$ & $0.08(-0.04,0.24)$ \\
\hline LITHUANIA & $0.25(0.14,0.41)$ & $0.23(0.11,0.39)$ & $0.29(0.18,0.44)$ \\
\hline LUXEMBOURG & $0.15 \quad(-0.02,0.41)$ & $0.09(-0.03,0.26)$ & $0.09 \quad(-0.06,0.30)$ \\
\hline MALTA & $-0.16(-0.30,0.04)$ & $-0.08 \quad(-0.18,0.08)$ & $-0.04(-0.16,0.12)$ \\
\hline NETHERLANDS & $0.38 \quad(0.24,0.55)$ & $-0.12 \quad(-0.23,0.03)$ & $0.26 \quad(0.09,0.51)$ \\
\hline POLAND & $0.18(-0.01,0.45)$ & $-0.22(-0.47,0.34)$ & $0.01 \quad(-0.25,0.39)$ \\
\hline PORTUGAL & $-0.24(-0.38,-0.04)$ & $-0.51(-0.64,-0.33)$ & $0.06(-0.11,0.27)$ \\
\hline ROMANIA & $0.12(-0.01,0.36)$ & $-0.50(-0.66,-0.22)$ & $0.21 \quad(0.10,0.38)$ \\
\hline SLOVAK REP. & $0.36(0.25,0.52)$ & $0.32(0.20,0.47)$ & $0.47 \quad(0.33,0.70)$ \\
\hline SLOVENIA & $0.19(0.08,0.34)$ & $0.02 \quad(-0.10,0.18)$ & $0.17 \quad(0.05,0.32)$ \\
\hline SPAIN & $0.16(0.09,0.27)$ & $0.01(-0.11,0.20)$ & $0.37 \quad(0.31,0.46)$ \\
\hline SWEDEN & $0.42(0.29,0.60)$ & $0.71 \quad(0.60,0.85)$ & $0.62 \quad(0.52,0.79)$ \\
\hline
\end{tabular}


